\title{
CHEMICAL CORPS: BREAK GLASS IN CASE OF WAR
}

\author{
A MONOGRAPH \\ BY \\ Major David L. Wilcox \\ Chemical Corps
}

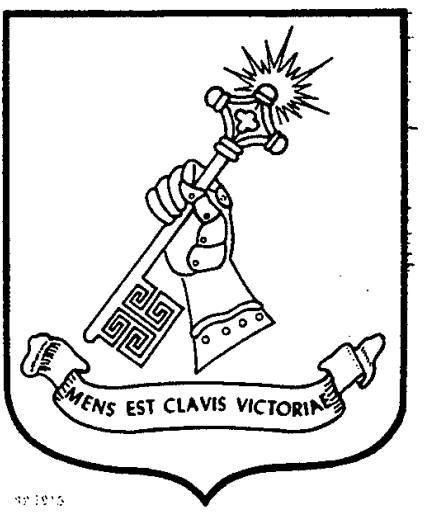

School of Advanced Military Studies United States Army Command and General Staff College

Fort Leavenworth, Kansas

First Term AY 97-98

Approved for Public Release Distribution is Unlimited 


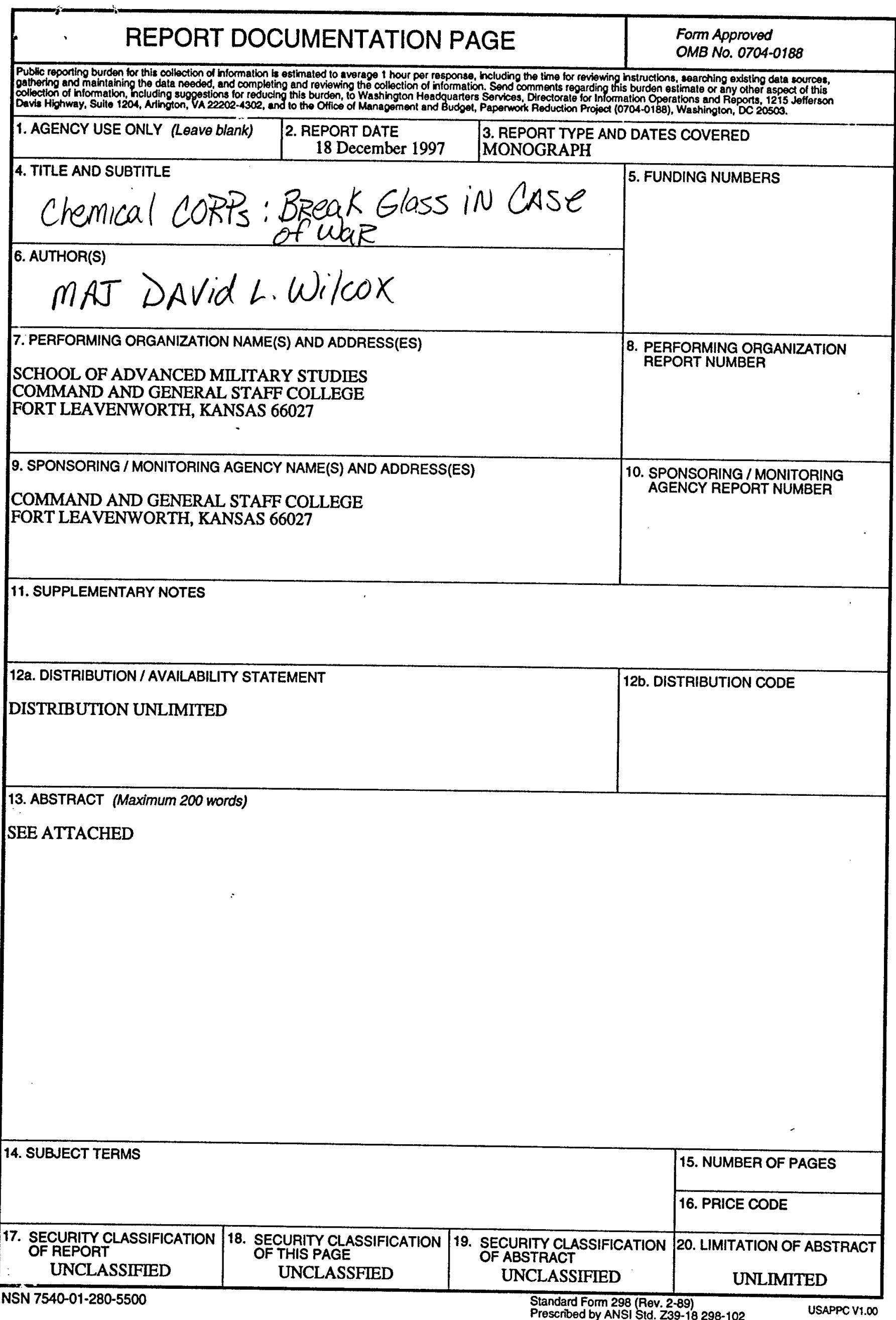




\title{
SCHOOL OF ADVANCED MILITARY STUDIES \\ MONOGRAPH APPROVAL
}

\author{
Major David L. Wilcox
}

Title of Monograph: Chemical Corps: Break Glass in Case of War

Approved by:

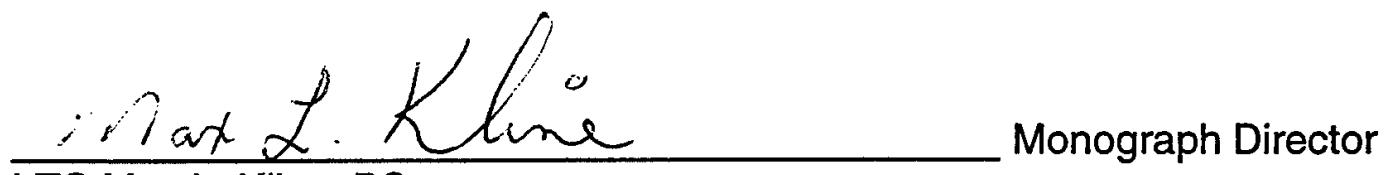

LTC Max L. Kline, BS
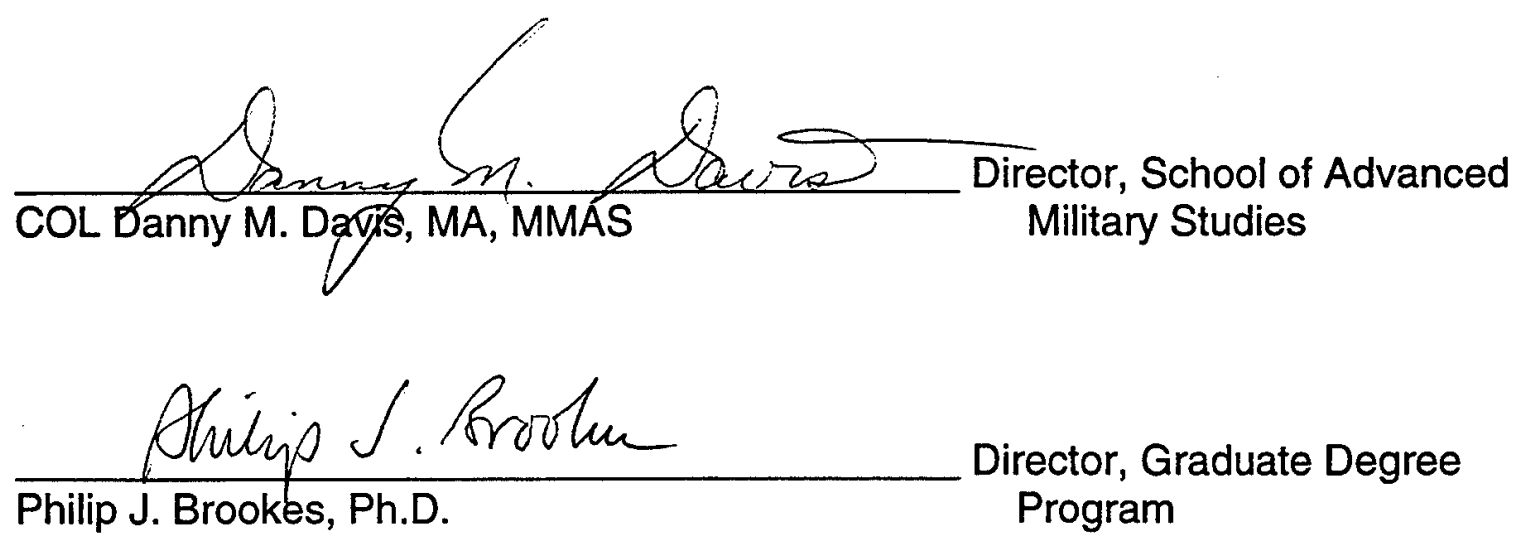

Accepted this 18th Day of December 1997 


\section{ABSTRACT}

CHEMICAI CORPS: BREAK GLASS IN CASE OF WAR bY Major David I. Wilcox, USA, 40 pages.

The threat or use of chemical weapons is a likely condition of future warfare - including the early stages of war, to disrupt operations and logistics. We are living in an age in which potential adversaries, who lack the means to confront the U.S Army in a conventional conflict, may reach for chemical weapons to countervail our technological and operational advantages. To meet this challenge, Army forces must be properly trained and equipped to operate effectively and decisively in the face of chemical weapon attacks. Brigade performances in chemical defense operations is the focus of this monograph. These operations are to defend against and, if used, manage the aftereffect of a chemical attack.

In spite of tremendous legislative support given to chemical readiness throughout the Armed Services in recent Government Accounting Office and Quadrennial Defense Review reports and the National Defense Strategy, US Army Brigades are insufficiently trained to operate on a chemically contaminated battlefield.

Chemical weapons have had a negative impact on Army operations since their first use in WWI. Today soldiers suffer from the same lack of training as those in WWI. Brigades enter into a mission totally unprepared for what may lie ahead. Intelligence-gathering assets are not poised to include enemy indicators about chemical weapons. Decontamination operations are afterthought operations and therefore are unsuccessful. This leaves the question, "Could Brigades conduct chemical defense operations if their lives depended on it?" The answer is no. 


\section{Table of Contents}

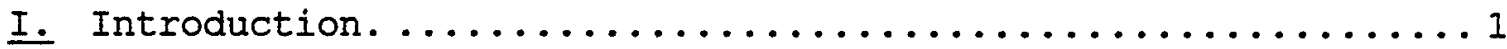

II. Historical Perspective. $\ldots \ldots \ldots \ldots \ldots \ldots \ldots \ldots \ldots \ldots$

A. Chemical Warfare on the Modern Battlefield: WWI. .......4

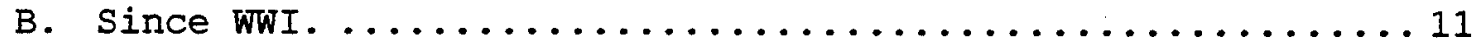

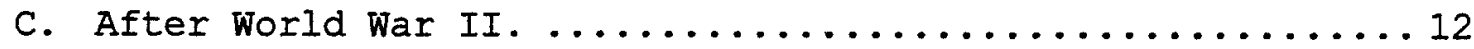

D. Desert Shield and Desert Storm. ................. 15

III.Today's Strategic Importance: Why Train. ............. 17

IV. Chemical Training Scenarios and Unit Performance

at the National Training Center. .................. 20

v. Conclusion. . . . . . . . . . . . . . . . . . . . . . . 38

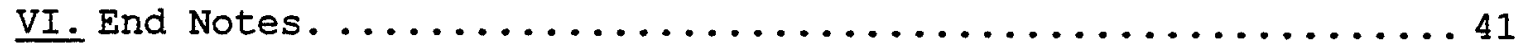

VII_Bibliography $\ldots \ldots \ldots \ldots \ldots \ldots \ldots \ldots \ldots \ldots \ldots \ldots \ldots$ 


\section{Introchaction.}

The military legacy for the twentieth century will be the development of weapons that destroy on a imposing scale. The first of these, chemical weapons, was significantly employed on the battlefield for the first time in World War I (1914-18). Invisible clouds of poisonous gases, released to envelop large numbers of troops simultaneously, without warning, caused more than a million casualties. The slow and excruciating action of the poisons, which absorb through the skin or inhaled through the lungs, horrified the public because it caused unnecessary suffering of the victims.

Since World War I, chemical weapons have been used sporadically throughout the century in smaller wars, mainly against poorly equipped opponents that lacked protective equipment. New and more toxic varieties, including nerve gases matured during World War II, but for reasons unrelated to the Geneva Protocol they were not employed at that time. And along with chemical weapons came the development of sophisticated means of delivering the toxic chemicals, such as bombs, missiles and special aircraft.

Although the traditional chemical warfare threat posed by the former Soviet Union has diminished with the USSR's breakup, the vulnerability that chemical warfare (CW) will be used has increased. The proliferation of $\mathrm{CW}$ agents is well known and documented. Two major factors behind this explosive rate of spread 
for chemical weapons are opportunity and cost. The opportunity to acquire or develop $\mathrm{CW}$ agents has probably never been more elevated. The technology is well established and the skills needed are the same as required for commercial pesticide production or operations requiring fermentation. Equipment for production is readily available and supplied on the open market. Compared to the cost for similar capability offered by nuclear or conventional forces, the price tag for these weapons is quite low.

U.S. Army troops, regardless of rank or branch, must be prepared to survive on a contaminated battlefield. The threat or use of chemical weapons is a likely condition of future warfare including the early stages of war, to disrupt operations and logistics. We are living in an age in which potential adversaries, who lack the means to confront the U.S Army in a conventional conflict, may reach for chemical weapons to countervail our technological and operational advantages. To meet this challenge, Army forces must be properly trained and equipped to operate effectively and decisively in the face of chemical weapon attacks. This requires that the Army improve its capabilities to locate and destroy chemical weapons, preferably before they can be used, and defend against and manage the consequences of chemical weapons if they are used. Chemical defense operations are the focus of this monograph. These operations are to defend against and, if used, manage the aftereffect of a chemical attack.

The consequences of chemical weapons used on the battlefield have not been a factor for the U.S. Army since World War I. 
However, the hypothesis that enemy forces could use them has played a major role in the army's chemical deterrent program, reaching down to the lowest level, the individual soldier. The US Army can not rely upon the nuclear and conventional retaliation threat to prevent the use of chemical weapons by an adversary in future wars. The retaliation threat was the perceived reason that Iraq did not use chemical weapons in the Persian Gulf war. In the case of Third World radicals, chemical weapons could be the weapons of choice to level the playing field.

In spite of tremendous legislative support given to chemical readiness throughout the Armed Services in recent Government Accounting Office and Quadrennial Defense Review reports and the National Defense Strategy, US Army Brigades are insufficiently trained to operate on a chemically contaminated battlefield. In fact, chemical defense training is not a high priority at any level of command except in the Chemical Corps. Recent Government Accounting Office reports did indicate that deficiencies in readiness that existed prior to and during the Gulf War are still in existence today. Routinely, units perform poorly in a contaminated environment at the National Training Center, the Army's premier training facility. As a result, the US Army remains vulnerable to chemical attacks and may sustain significant chemical warfare losses on the battlefield of the future.

The purpose of this monograph is to examine army doctrine and tactics as executed in training scenarios at the National Training Center. Using historical and field training exercise data, this 
monograph will examine the US Army's tactical abilities to successfully accomplish its mission on a contaminated battlefield. Questions to be answered: Are the NTC scenarios setting the proper chemical warfare conditions for units to be successful if faced with chemical weapons on the future battlefield? Are units trained and ready to operate in a contaminated environment, and if not what are the training deficiencies? Finally, this monograph will make recommendations to remedy training deficiencies, when deficiencies exist.

The principles of chemical defense operations, specifically, contamination avoidance, protection, and decontamination will be the criteria used to evaluate units' training readiness at the National Training Center during tactical scenarios.

Before answering the question: Can U.S. Army Brigades operate tactically on a chemically contaminated battlefield? This monograph will explore the need to have such a capability. Using past historical military uses of chemical weapons and their effectiveness on units to illustrate the need for such a capability or if indeed the need exist.

\section{Historical Perspective.}

A. Chemical Warfare on the Modern Battlefield: WWI.

Historically, chemical warfare has existed and been used on the battlefield from 431 B.C through the 20th Century. It can be traced as far back as the Peloponesian War. For example, the Spartans used wood, saturated with pitch and sulfur, to create a poisonous and suffocating 
gas during their sieges of Platea and Pelium. The attempt failed due to unsuitable weather conditions. However, a successful attempt was made five years later using the same procedure. ${ }^{1}$ Its most recent uses are in 1988, during the war between Iran and Iraq and, possibly, the Persian Gulf War, 1991. ${ }^{2}$ But, World War I would be the first major conflict involving massive use of chemicals as a weapon.

The First World War caused dramatic changes to land warfare. The airplane debuted as an effective observation and fighting asset. Tanks added speed, mobility, and armored offensive vehicles on the ground. And for the first time, on a large scale, chemical weapons were used, adding to the already intensifying "fog of war" on the modern battlefield.

During World War I, on the western front, a stalemate developed between German and Allied Forces; neither side was able to break through the other's front line forces. A checkmate defense ensued, static trench warfare characterized the Western Front. Mass offensive strategies dominated the tactics for both sides at the beginning of the war. Neither side envisioned the need for large-scale industrial preparation for war. The belligerents believed that the initial stockpiles of weapons and ammunitions would be enough for this brief war. They did not see a lengthened war.

The Germans conducted a series of attacks and counterattacks in order to break the front line of the British and French defenses. Their attempts failed. When a stalemate developed, the German high command seized the opportunity to use chlorine gas along the front lines of the Allied defense. The use of chemicals offered a means of overcoming the 
stalemate, clearing the trenches and restoring German momentum to the campaign. ${ }^{3}$

So on 22 April 1915, near Ypres Belgium, German forces applied lethal gas in massive quantities as part of their tactical plan." Along a five-mile front, German forces placed cylinder filled chlorine tanks. When the Germans had the right weather conditions, winds blowing east to west, they released the gas. The gas attack surprised the French forces and they were unprepared. Two French divisions, seeing the unexplained cloud coming toward them, panicked and fled, leaving a five-mile gap in the Allied defense. The Germans estimated 15,000 casualties, including 5,000 deaths. 5

These losses, along with the shock and panic resulting from the surprise introduction of a new weapon, could have been a serious blow to the Allies. ${ }^{6}$ The success of the gas attack was a surprise to the Germans. German commanders looked upon the plan with liberal consent, their plan did not include a reserve to exploit the success. Therefore, Allied forces were able to reconsolidate and reinforced the gap during the night with a reserve force. ${ }^{7}$ However, the use of poisonous gas had proved what chemical warfare could do to unprepared soldiers. This first use of poisonous gas by the Germans triggered the race between all warring powers to further develop this new use of chemical warfare. Their emphasis was to mature the use of chemical warfare through their tactical employment and technological advances.

The Allied forces used the lessons learned from this gas attack at Ypres to further their own tactical use of chemical warfare and defensive measures against the use of chemicals by the Germans. Within 
days of the event in Ypres, Belgium, the Allied forces developed a crude gas mask to be used by the soldiers for protection against chemical vapors. The masks were chemically impregnated gauze pads which enhanced the filtration of poisonous gases. Although effective against known chemical agents at the time, the mask was uncomfortable to wear and made soldier tasks twice as hard to execute. By the end of 1916, all warring powers had chemical weapons and reasonably effective gas masks against their use. ${ }^{8}$

When the U.S. entered the war in 1917, it did so totally unprepared for chemical warfare. The information being sent back by U.S. observers of the war was being censored by the Allied commands. The Allies were interested in getting the U.S. committed to the war and only allowed information that would enhance that goal to reach the U.S. The U.S. War Department had little information about chemical warfare. With little information, they did not seriously view the threat that chemical warfare purposed. Therefore, the U.S. had little information as to the extent chemical weapons were being used on the battlefield. Chemical warfare was not mentioned in a study about World War I published by the U.S. Army War College in the summer of 1915 . An updated version was published in the fall of the same year, surveying the development in weapons, equipment, and force structuring, but again, chemical warfare was not mentioned. Consequently, the U.S. Army entered the war without a doctrine, protective equipment or an adequate training program for chemical warfare. And, initially, U.s. forces depended on the Allies for training and equipment. ${ }^{9}$ 
Once committed to the war, the U.S. Army created the Gas Warfare Service to solve training and equipment issues. As advance elements for the American Expeditionary Force, Major General John J. Pershing and his staff saw the importance chemical weapons played on the European battlefield. They pressed the war Department for immediate action to establish a force to focus on the challenges of this new weapon. ${ }^{10}$ The Gas Warfare Service focused on the development of tactics, training soldiers, and defensive equipment to countermeasure the use of chemical weapons by the Germans. At this point in the war, each Allied force had its own internal agency working chemical weapons issues.

The use of chemical weapons increased as the war progressed. Both sides, German and Allied, made a determined exertion to develop new agents and tactics that would overcome the other's countermeasures. Chemical weapons consisted of two types, persistent and nonpersistent Nonpersistent agents would be used minutes before an attack so that it dissipated prior to their units arrival. Using this technique, attacking soldiers were able to fight unimpeded by cumbersome protective masks while forcing the opponent to wear such items. Persistent agents were used to protect the flank of an advancing unit, or to deny key terrain to the enemy, or on a specific unit to deny them freedom of maneuver.

The Germans held the technological advantage and they were the first to produce mustard gas, a persistent agent, which remained in the area for days. Mustard gas had a delaying action that caused blistering and skin irritation, and if left untreated caused death. The gas mask, 
alone, provided little protection and so German and Allied forces developed protective clothing to guard against the effects of mustard gas.

The Allies would take a year after the first mustard attack in July 1917 by the Germans to duplicate the same agent. The German tactical employment of mustard gas called for its use while in the defense against attacking Allied forces. Additionally, common to both sides, mustard gas attacks were used against logistic elements, artillery batteries, and repositioning routes of reserve forces.

By 1918, it was apparent to the belligerents that chemical warfare was an extremely versatile weapon, manageable to almost any situation. ${ }^{11}$ The overall use of chemical weapons stressed surprise, to catch the enemy off guard and unprotected. Chemical weapons provided commanders' flexibility in their plans. It was apparent that chemical warfare had three central characteristics: it was extremely versatile weapon, tractable to almost any tactical situation; the logistic requirements complicated the battlefield; and its employment demanded unprecedented refinement of individual and unit training. ${ }^{12}$

Earlier in the war, the tactical and delivery methods of chemical warfare varied to some degree between the Allies and Germans. German chemical warfare doctrine and direction came primarily from the scientist who developed the gases. While the Allied doctrine came from the military. This difference gave Germany a significant lead in chemical warfare because of their familiarity with the capabilities and characteristics of gas. ${ }^{13}$ However, these variations became less noticeable during the latter stages of the war. The Allies combined 
the efforts of the military and scientific communities for further development of chemical warfare. By November 1918, all warring powers were using similar tactical employment doctrine, delivery systems, and chemical agents. ${ }^{14}$

These tactical uses of chemical warfare were made possible by the advancement in artillery delivery systems. Although the French were the first to develop artillery delivered chemical munitions, the Germans, having the technology advantage, were able to exploit this new technology. German It. Col. George Bruchmuller, considered an artillery genius because of his success on the battlefield, developed tactical doctrine focused on shelling high payoff targets. ${ }^{15}$ Artillery batteries would fire large concentrations of chemical gases at a known or suspected enemy location and, after a period of time, re-fire the same mission.

In summary, throughout the war, there was a tactical and technological race between the warring powers to develop the use of chemical weapons. In World War I, chemical weapons were not decisive in the outcome of the war. They, however, were effective for a number of military purposes, namely, terrain denial, isolation of reserve forces, and disruption of logistical routes.

WWI showed that well-protected soldiers had lesser casualty rates than those whose protection was poor. Although, well-protected soldiers suffered casualties due to inadequate warning and reporting, poor training and discipline. The use of or fear of use, chemical weapons degraded morale, by enforcing the need for constant alertness and the prolonged adoption of protective measures. Thus, chemical 
weapons had an important psychological effect. It created uncertainty in the soldier and added to the fear and stress of the battlefield. ${ }^{16}$

As the war progressed, chemical weapons were used more and more as each side learned better ways to tactically employ them and improved the artillery delivery systems. For the civilian decision-makers and military leaders, chemical weapons received no less favorable reaction than any other newly introduced weapons of the war.

\section{B. Since WWI.}

Prior to World War II, Italy used chemical weapons in their war with Ethiopia, and Japan in their war with China. The Ethiopian and Chinese nations did not possess the necessary protective equipment to guard against the effects of chemical warfare, nor the ability to respond in kind. Subsequently, both sides suffered heavy and unnecessary casualties. Ethiopia reported 15,000 chemical causalities, including an inconclusive number of civilians who were intentionally targeted. ${ }^{17}$ Japan continued to use chemical weapons against the Chinese achieving minor tactical successes until 1945 .

After the wide spread use of chemical warfare in World War I, there was concern by all nations involved in World War II that history would repeat itself. World War II is significant because it serves as an example of a conflict in which the belligerents were preparing and planning to use chemical weapons, yet refrained from employing them. Although, Germany used poisonous gases extensively in their concentration camps where millions died. Both 
sides considered the concept of employing chemical weapons important enough to divert resources [civilian labor, research and development, manufacture and storage].

Most nations involved in WWII had stockpiles of chemical weapons. Only Germany had the advantage of a new class of chemicals called nerve agent. The new nerve agent, Sarin, was discovered by Dr. Gerard Schrader in 1936, and led to the development of a more lethal agent, Tabun. ${ }^{18}$ By 1944 , Germany accumulated mass quantities of chemical agents and stockpiled 2,000 tons in artillery shells and another 10,000 tons in bombs. ${ }^{19}$

The retaliation response was the main reason neither side used chemical weapons during World War II. In 1942, President Roosevelt of the United States warned that his Allies would make 'the fullest retaliation' if Japan and Germany fought with the aid of gas. ${ }^{20}$ His warning was effective.

Germany built up her stockpile of chemical weapons by war's end, but restrained from using it for fear of retaliation on German territory. Additionally, Adolph Hitler's exposure to toxic gas during WWI as a private may have been a contributing factor to Germany's reluctance to use chemical agents during WWII. For the same reason, retaliation, Japan stopped using chemical weapons against the Chinese.

C. After World War II.

Following World War II, Egypt was the first nation to use chemical weapons. During the civil war in Yemen, from 1963 until 
1967, Egypt used chemical weapons from the former Soviet Union. There were at least 40 incidents and the number of casualties was revealed to be 400 dead and 900 seriously wounded. ${ }^{21}$ Egypt used aircraft to drop nerve gas on military targets throughout Yemen. Although chemical weapons were not totally decisive, Egypt did gain a tactical advantage by using them.

In Vietnam, the US Army used tear gas in order to drive Vietnamese fighters out of underground tunnels. ${ }^{22}$ In addition, the US Army sprayed a chemical defoliant on the jungles in Vietnam in order to kill the cover and concealment used by enemy forces. Agent Orange was the code name for the herbicide developed for the military, primarily for use in tropical climates. Although the genesis of the product goes back to the 1940 's, serious testing for military applications did not begin until the early 1960's. The product was tested in Vietnam in the early 1960 's, and brought into ever widening use during the height of the war (1967-68), though it's use was diminished and eventually discontinued in 1971. The morality, legality, and medical pathology of the U. S. use of chemicals in Vietnam remain a matter of continuing debate. ${ }^{23}$

The United Nations has documented use of chemical weapons in several Third World countries. ${ }^{24}$ In 1975 , the National Freedom Army of Laos and North Vietnamese forces used chemical weapons against the opposition and villagers who supported them. In Cambodia, the Vietnamese used chemical weapons against the Khymer Rouge. Significantly, in both cases, chemical weapons were used not only against military targets, but also against civilian populations. 
The 1980's have produced the most widespread use of chemical weapons since 1918. The best known use of chemical weapons in the late $20^{\text {th }}$ Century is the war between Iran and Iraq, beginning in 1980. Iraq was known to use chemical weapons to gain the tactical advantage. Iraqi use of chemical weapons was directed against two main targets: Iran's army and Kurdish civilians as punishment for their support of the Iranians.

Early in the war, Iran had seized initiative through a series of offensive operations. Iraq used chemical weapons as a means to regain lost territory, particularly, when Iran hard pressed defending forces. Iraq's use of chemical weapons was responsible for around 10,000 Iranian casualties. ${ }^{25}$ Additionally, Iraq used persistent agent in the defense and for flank protection, while nonpersistent agents were used in the attack. However, their use did not bring the end of the war sooner nor make a significant impact during the course of the conflict.

Iraq demonstrated that chemical weapons have a battlefield utility, either complementing the tactical effects of conventional weapons or forcing an enemy into a degraded operational posture. Those effects were similar to WWI. Soldiers had to wear hindering protective equipment. And, the Iranians experienced difficulty in command and control procedures.

Iraq has encouraged the proliferation of chemical weapons, as well as other weapons of mass destruction, within the Middle East and Far East countries. By demonstrating that a nation can develop and deploy these weapons in defiance of international disapproval 
and with no regard for international law. ${ }^{26}$ Subsequently, other countries will assess the potential of chemical warfare for their own use. Due partly to the weak international response to Iraq's repeated breaches of the Geneva Protocol.

C. Desert Shield and Desert Storm.

While the Iran / Iraq War is a rather dull memory in the minds of many. The invasion of the sovereign state of Kuwait by Iraqi troops in 1990 brought world attention to the potential use of chemical weapons on the battlefield. While U.S. Military doctrine requires training of troops in the area of chemical defense, Desert Shield / Storm brought to life the true fear behind the agents involved.

"Iraq had developed a substantial chemical weapon capability including research facilities; stockpiles of chemical weapon munitions; a variety of delivery systems; and the doctrine and training to employ integrated chemical weapons and conventional fires."27 Already, Iraq had demonstrated its willingness to use chemical weapons in their war with Iran. Why would this war be any different?

With the threatened use of chemical weapons by the Iraq's, US forces underwent extensive chemical defense training. Chemical defense training was conducted at every echelon, from individual survival skills to large-scale unit sustainment operations. ${ }^{28}$ These same skills that required immediate attention for training to ensure every soldier was able to perform, are the same skills that 
were found to be lacking in unit training programs before and after the war. Only with the perceived threat of chemical weapons on the battlefield did commanders provide the necessary resources and conduct the training required. Much of the training was conducted in Saudi Arabia with troops already within striking distances of Iraq's chemical weapons munitions, much like the units entering WWI.

After the war, published reports have contradicted the readiness of units and individuals to operate effectively in chemically contaminated environment. One such report stated that despite some deficiencies that overall commanders and troops had confidence in the ability to survive chemical weapon attacks and continue operations. ${ }^{29}$ while the other report stated just the opposite: shortcomings in equipment, training and medical were Iikely to result in needless casualties and degradation in warfighting capabilities. ${ }^{30}$

For some unknown reason, the Iraqi's did not use chemical weapons during the Persian Gulf War. Perhaps they did not use them because the weather conditions were not right. Or, Iraqi commanders failed to implement the chemical weapons plan. Maybe, the implied threat of retaliation by the United States was enough to discourage their use. But, clearly, it was within Iraqi's capability to use chemical weapons just as they are within the capabilities of others.

Could US Army soldiers survived if chemical weapons were used during the war? Perhaps, but the loss of lives and psychological 
impact on the remaining force would have had a devastating effect. This effect would have taken an extremely long time to recover from and impacted on the current operation. ${ }^{31}$ The "will" of the American people would truly have been tested.

\section{Today's Strategic Importance: Why Train.}

"Strategy is one of the most important tools of politics, and even in peacetime political calculations must to a great extent be based on the military capabilities of friendly and hostile nations." 32 The national security concerns of the United States have undergone significant changes in the years since the dissolution of the Soviet Union. The fall of the former Soviet Union that brought the end of the cold war era and the advent of the "New World Order" has altered the battlefield calculus and lowered the threshold for chemical employment.

"Particularly ominous is the fact that the states now working the hardest to develop chemical weapons are, for the most part, located in unstable regions of the world where bitter and unresolved rivalries have erupted into war in the recent past and hold the prospect of doing so again. Thus it seems possible that the world will see more chemical weapons used in regional conflicts than in any other time in history." 33

As part of the annual reporting by the Department of Defense to Congress, the US Army is required to report on the status of nuclear, biological, and chemical training. The report summarizes the readiness status of the force and the measures being taken to 
provide realistic training in exercises. ${ }^{34}$ This report to Congress is directly linked to our National security Strategy and the Military Strategy.

The 1997 National Security Strategy implies that weapons of mass destruction, including chemical weapons, pose the one of the greatest threat to global security. ${ }^{35}$ And, deterrence, through nonproliferation initiatives, is one of the ingredients needed to reduce the threat posed by nations possessing weapons of mass destruction - chemical weapons. The goal of deterrence is to maintain peace and stability by convincing potential adversaries that the cost of aggression, or in this case the use of chemical weapons, would significantly exceed any possible gain. Additionally, chemical defense training and readiness are critical elements of deterrence. That is, Brigades must be trained, equipped, and demonstrate the ability to survive, fight, and win in a contaminated environment.

Now that the world is more complex and integrated than at any pervious time in history, a solid deterrence policy has increasing importance. "The growing global interdependence means that events throughout the world impact on the United States with increasing frequency." ${ }^{36}$ Currently 24 countries have been confirmed to have, or are suspected to have, chemical weapons.

The future threat is more complicated now than during the Cold War era. Adversaries in regional conflicts, and even non-state players will have limited chemical stockpiles and capabilities. ${ }^{37}$ Many of these adversaries possess the required technical expertise 
and delivery means necessary to threaten rivals at great distances.

Implications from a political-military perspective is that, of those states pursing a chemical weapon and missile programs, a significant number pose direct threats to stability in vital regions where the us has long standing security commitments and the forward presence of its forces. ${ }^{38}$ These areas include the Middle East, where countries are known to have used chemical weapons in this century, and North Korea with its ballistic missile program.

Many of these states view chemical weapons as combat multipliers. That chemical weapons are effective deterrent weapons against regional aggression and also a proven offensive weapon as we11. ${ }^{39}$ Brigadier VK Nair of the Indian Army hints at the use of chemical weapons as a preferred technique to defeat the us military. ${ }^{40}$ This implies that the key for success is the exploitation at the strategic and operational levels of the tactical use of chemical weapons.

Chemical weapons, including nuclear and biological weapons, are no longer seen as a weapon of last resort, but rather a weapon of choice. They can be used at any time during a conflict for political and psychological, as well as military, purposes. As such, US Army Brigades could find themselves confronting an adversary willing to use chemical weapons to asymmetrically skew the battlefield. 
A brigade's vulnerability to a chemical attack constitutes a critical disadvantage, exploitation of which would jeopardize the operational and strategic objectives of the overall operation. The use of chemical weapons can demoralize an opponent, inducing fear and anxiety, thereby complicating the command and control process. Thus permit an adversary the opportunity to achieve tactical and strategic victories. That is why brigades must conduct their wartime tasks with zeal and be able to do them, if necessary, in a contaminated environment.

\section{Chemical Training Scenarios and Unit Performance at the National Training Center.}

The National Training Center (NTC) is located approximately 37 miles northeast of Barstow, California in the High Mojave Desert midway between Las Vegas, Nevada and Los Angeles, California. The NTC mission is to provide tough, realistic combined arms training at the Brigade level using both live fire and opposing forces. The National Training Center has a computer-driven, live-fire complex with sophisticated targetry, a full-time opposing force, a state-of-the-art instrumentation system that monitors training battles, and a full-time team of combat trainers who observe and control units during exercises. ${ }^{41}$ Today, it is considered to be the premier training site of the U.S. Army: its purpose is to take the troops as close to the edge of war as the technology of simulation and the rigors of the environment will allow. 
Brigades go to the National training Center (NTC) to train and execute their wartime tasks in full-scale field exercises. They have the opportunity to demonstrate their abilities under the most realistic conditions, short of actual war. All aspects of combat arms operations are available to the brigades. "Combined arms warfare is the simultaneous application of combat, combat support, and combat service support toward a common goal." 42

Under combined warfare conditions, Brigades have the opportunity to evaluate their execution of doctrine, tactical techniques, and procedures, and their Mission Essential Task List. The higher headquarters of the brigades, in conjunction with headquarters at the NTC, develop the scenarios. These scenarios range from force projection operations, operations other than war, and, offensive and defensive operations executed against an opposing force. These wide ranges of possible scenarios allow the brigades to examine their performance conducted during the operation.

This portion of the monograph will examine the performance of units using two scenarios in a simulated chemical contaminated environment. Using the three principles of chemical operations and doctrine, the monograph will identify shortfalls in planning, preparation, and execution by units. The principles of chemical operations are avoidance, protection, and decontamination. ${ }^{43}$

Brigades operate at the tactical level of war. They conduct tactical missions consisting of battles and engagements to accomplish military objectives as outlined by the next higher 
headquarters. ${ }^{44}$ Performance of these tactical missions under chemical warfare conditions are poor, it shows a direct correlation to a unit's inability to conduct and sustain operations.

Chemical warfare serves several purposes - terrain denial, integrated with obstacles, shape the battlefield, harassment, attrition, exhaust morale and weaken the opponent's effectiveness. The enemy can use any one of these separately or in concert with one another to achieve the desired effects upon an opposing force. Used against inadequately protected and untrained soldiers, chemical warfare can cause a large number of casualties, as the experience in WWI demonstrated.

When chemicals are introduced on the NTC battlefield, units experience degradation in mission accomplishment or, altogether, mission failure. The effects of chemical weapons cause disruption of operations through the individual and unit performance degradation caused by donning of protective equipment, adapting protective measures and added burden to leader tasks.

At the NTC, a Brigade conducting a deliberate attack against a defending enemy encountered the effects first hand. A battalion task force was moving along an axis of advance to conduct a breaching operation, a nonpersistant chemical agent was used on the lead element. Although the intelligence and chemical officers predicted nonpersistent chemical agent attacks, neither the lead element nor the brigade took the necessary precautions of avoidance and protection. 
Furthermore, the Fox vehicles were positioned at the battalion task force's operation post. First introduced to the U.S. Army in the Persian Gulf War, the fox vehicle is a self contained NBC reconnaissance vehicle capable of a wide variety of NBC missions, one of which is detecting chemical agents. Thus, not prepared for the nonpersistent agent, the Brigade suffered heavy casualties, impaired synchronization of the brigade operation, diminished agility and tempo, and disrupted battle command.

Understanding what happened and why it happened goes back to the beginning of the scenario. The brigade received the mission from the division to conduct a deliberate attack against a defending enemy. Once they understood the mission as laid out in the order, the military decision-making process (MDMP) takes over. ${ }^{45}$

The MDMP is a single, established, and proven analytical process. It is an adaptation of the Army's analytical approach to problem solving and assists the commander and staff in developing estimates and a plan. The MDMP is a seven-step process requiring certain actions by the commander and staff officers. ${ }^{46}$ The brigade conducts the initial process as long as time will allow, refining the products as they go along.

For the scenario above, lets examine only those actions required to predicate and manage the enemy's use of nonpersistent agent as they relate to the MDMP. Understanding the enemy's doctrine of chemical warfare in a defensive posture is critical in predicting when and where they will use it, the threat. Battlefield success depends largely on 
the ability of the Brigade to see the battlefield. They must identify how the enemy is using the ground to minimize the risk of surprise.

The Brigade does this by the intelligence preparation of the battlefield (IPB). The IPB process achieves success when all available intelligence-gathering assets are focused to obtain well-chosen and specifically tasked priority intelligence requirements (PIRs). ${ }^{47}$ The commander, intelligence officer (S2) and chemical officer use the information for development of the IPB.

IPB is a systematic, continuous process of analyzing the threat and environment in a specific geographic area. It is conducted prior to and during the command's initial planning for an operation. Also, it is conducted during an operation and well into the next. ${ }^{48}$ The entire staff uses the IPB to assist in the identification and to answer the commander's priority intelligence requirements (PIR). IPB begins in the mission analysis phase of the MDMP and continuous throughout the operation.

Chemical IPB plays a key role in two ways. First, a clear picture of the threat allows the commander to make informed decisions about when and where protective measures need to be in placed. Second, the data is used to develop the chemical reconnaissance and surveillance plan. The chemical reconnaissance and surveillance plan is not a separate plan from the 52 's plan, but an integrated part. Avoidance is a key element of the principles of chemical operations.

The S2 and chemical officer determined the enemy would use nonpersistent agent at the breach site against lead elements 
conducting the breach. This information went into the operations order and disseminated among the units. No analysis was done to determine what impact if any, or the actions required by the unit or individuals, if they encountered nonpersistent chemical agents at the breach site.

While only the lead elements of the task force entered into the nonpersistent agent, the loss of momentum for the Brigade attack was devastating. The brigade operations halted for over 30 minutes in order to determine what actions needed to be taken. The task force suffered casualties because soldiers were not in protective clothing. Command and control was momentarily disrupted because leaders and soldiers had to stop what they were doing and put on their mask. And, talking through a mask voice miter makes passing instructions more difficult to understand.

The Brigade violated two principles of chemical operations, avoidance and protection. Avoidance measures were not discussed prior to mission execution. The Brigade commander did not give guidance for chemical defense operations in his guidance prior to executing the MDMP process. Therefore, a plan was not developed. Additionally, individuals or units did not employ or enforce protective measures.

Once the Brigade determined the chemical agent type, nonpersistent, and assessed the casualties, they continued the attack. But, momentum and tempo was lost and the Brigade conducted a piecemeal attack. The massing of combat power at the decisive point was unachievable and the enemy won the battle. 
Applying tactics is "the art and science of employing available means to win battles and engagements. Tactics is battlefield problem solving..."49 The Brigade tested its ability to apply tactics on the battlefield and failed. In this particular scenario, once the Brigade resolved the requirement about the enemy's use of chemical weapons. The $\mathrm{S} 2$ and chemical officer deduce a plan to answer the requirement.

The plan encompasses the enemy's possible employment of chemical weapons and where they are likely to use them. With this, a template is made of possible chemical target locations and placed on the S2's enemy situational template A situational template is a graphic portrayal of the enemy's course of action. These templated areas become named areas of interest (NAIs). Simply stated, if something happens in these areas the brigade commander wants to know about it.

The NAI demands an asset be dedicated to overwatch the area at the prescribed time the event is expected. An ideal mission for the Fox vehicle. The Fox vehicle travels alongside the lead element. Placing the Fox vehicle in the right position to give an accurate assessment if nonpersistent agent is used.

Planning and preparation is key for implementing avoidance and protective measures. The brigade $\mathrm{S} 2$ and chemical officer determine where the enemy is most likely to use nonpersistent chemical agent. Then, concepts for avoidance are considered and planned. If avoiding the area is not an option, the plan minimizes the contact units encounter with the area. These 
concepts are part of the course of action, fully developed during the wargaming secession for the brigade.

A course of action assigns responsibilities for actions during the execution of the operation. It defines who, what, when, where and why. The how is usually determined by the responsible unit for that action. Wargaming is an attempt to visualize the flow of a battle. This process relies on a doctrinal foundation, tactical judgement, and experience. ${ }^{50}$

During this process, the $\mathrm{S} 2$ and chemical officer refine their method of answering where the enemy will use nonpersistent agent. And how the Brigade will overcome the enemy's efforts to halt the deliberate attack. The chemical officer is refining the chemical vulnerability analysis completed earlier in the process. Knowing that the Fox vehicle must travel with the lead element, placing it in the position to provide the Brigade with avoidance and protective measures.

The fox vehicle is able to obtain an instantaneous read of the chemical agent. Additionally, drivers in the lead element wear their protective mask. This allows the lead elements sufficient reaction time for protection measures. Applying this technique ensures the formation maintains speed and flexibility during movement. The brigade retains the freedom of maneuver and uptempo. These techniques are incorporated in training exercises for such an event as a reaction to the enemy's use of nonpersistent agent. 
The techniques are discussed and developed during the wargaming session. The chemical officer provides the expertise for placing the Fox vehicle with the lead element. The information is included in the reconnaissance and surveillance plan of the Brigade. The wearing of mask by the drivers is part of the Mission Oriented Protective Posture analysis conducted during mission analysis. ${ }^{51}$ This information goes into the order and rehearsed at the rehearsal.

The plan to overcome the enemy's use of nonpersistent agent is confirmed during the wargame. The key to success relies on information dissemination and rehearsals. Rehearsing key combat actions allows participants to become familiar with the operation and to translate the tactical plan into a visual impression. ${ }^{52}$ These visual impressions give units an orientation of the actions required to negate the enemy's use of nonpersistent agent.

The necessary steps for contamination avoidance and protection are completed during the planning and preparation phases of the operation. Everyone in the Brigade understands the actions required counteracting the enemy's use of nonpersistent agent against the lead elements of the task force. Leaders ensure individuals at the execution level are prepared for the reaction to nonpersistent agent.

The brigade begins the mission with drivers in mask only posture. The $\mathrm{S} 2$ and chemical officer monitor intelligence reports of the enemy's activities with regard to the use of chemical 
weapons. They use the reconnaissance and surveillance plan discussed earlier for this type of monitoring.

The lead elements approach enemy obstacles, the breach site. The enemy uses nonpersistent agent against them. The Fox vehicle is able to obtain a quick read that the cloud burst is nonpersistent agent and relays the information. Vehicles are continuing to move because the drivers are wearing the protective mask. Soldiers not in mask have the reaction time to do so without becoming a chemical casualty. The Brigade is now in a position to continue the operation unimpeded, maintaining momentum and tempo.

The reaction to the use of nonpersistent agent is one of many complex tasks that a brigade encounters during an operation with an uncooperative enemy. Overcoming this task begins with a thorough understanding of the mission, enemy threat and capabilities, meticulọs IPB, and, capabilities and limitations of organic assets. Applying the necessary doctrinal knowledge, tactical experience, and judgment to the operation, the Brigade defeats the enemy's use of nonpersistent agent.

In a similar scenario, another unit experiences the use of persistent chemical agent by the enemy. The enemy used a persistent agent along the purposed axis of advance of a battalion size task force. Although information was available that described the contaminated area, the battalion task force entered the area The Brigade lost a complete Task Force of combat power and logistic elements. The Brigade was unable to continue the mission. 
During the Situational Template (SITEMP) development, the S2 templated possible enemy persistent chemical strike locations. These locations became NAIs that supported the Brigades commander's PIR: He wanted to know when and where the enemy would use persistent chemicals to shape the battlefield. The s2 developed a Recon and Surveillance (R\&S) plan to answer the chemical NAIs and the remaining requirements of the PIRs. The R\&S plan did not include the FOX as an observer or active participant in answering the chemical PIRs. The s2 tasked units without the knowledge or capability for chemical reconnaissance.

Meanwhile, the chemical officer developed the NBC annex and assigned missions to the chemical assets. The chemical NAIs, nominated in the NBC annex, did not match those listed in the S2's R\&S plan. An indication that the chemical officer and 52 had not coordinated nor deconflicted their predictions. Additionally, the FOX was not given a clear mission that contained a task and purpose. In other words, the chemical officer nor chemical company commander developed a plan in conjunction with the S2's R\&S plan to answer the PIR. The annex had the FOX moving with the trail Task Force and responding to artillery strikes that might contain chemical agents.

The S2 and chemical officer conducted their planning separately, no coordination or parallel planning was done to overwatch the chemical NAIs. Up to the time the first vehicle entered the contaminated area, the Brigade had the necessary information to possibly avoid the area. An analysis of the information was not conducted, allowing the Task Force to blindly enter the contaminated area. The following information was 
available to the Brigade staff prior to the lead Task Force entering the persistent chemical strike area:

092204: IEW intercepts MSG / Special Munitions Fired at NK435090. 100014: Enemy artillery fired, $600 \mathrm{rds}$ at NK407096 / Q37 detects/ MSG sent to DS Arty Bn.

100250: Battle staff (night shift) suggest possible P-Chem strike (XO, BIC, and IEWSO) .

100337: IEW intercepts message / special munitions fired NK445095.

100345: FSO offers early $Q 37$ intercept / 600 rds at NK407096

(Battle staff decides not to post wants to confirm). 100547: IEW intercepts message / special munitions fired at NK3908.

100700: Spot report received / chemical strike at NK400097.

100703: First vehicle enters persistent chemical agent (no reaction by crew).

100705: Task Force commander ask Brigade TOC for any possible chemical agent locations: none given. The results were 78 vehicles and 176 personnel contaminated. ${ }^{53}$

Avoidable, maybe, if the chemical officer, in concert with the S2, had developed theories on the enemy's employment of chemical weapons. From that, NAIs are developed for inclusion into the $R \& S$ plan. The R\&S plan is developed to answer the Brigade commander's PIRs. The chemical NAIs are part of that plan. 
The R\&S planning for chemical NAIs require detail plans and can be broken down into two parts; getting the asset(s) to the observation post and the actions required by the asset(s) and units if a persistent chemical agent is found. The chemical officer and S2 decide early in the R\&S planning whom will confirm or deny the NAI.

R\&S planning considerations, by the chemical officer, are command and control, routes to and from the NAI, recon technique, security, marking procedures, and reporting channel. The technique listed below is one way to conduct R\&S planning - OP selection:

Step 1: You have identified the requirement for an op. This selection is done during the R\&S planning or identified during wargaming.

Step 2: Conduct terrain analysis for observation point location.

Step 3: Allocate the asset needed based on the mission to be performed.

Step 4: Select the OP site based on the terrain analysis, the mission, capabilities and limitations of the asset.

Step 5: Plan the insertion; routes, control points, hide positions, etc.

Step 6: Make necessary coordination; clear passage through friendly forces, deconflict terrain, establish controlled fire zones around OP site (Force Protection).

Step 7: Support the insertion/operation. Plan and coordinate indirect fires, IEW support, medical support, extraction, security, and resupply. 
Step 8: Execution.

The second part of this plan is the requirements to mark the area and provide a bypass route if necessary. This part of the plan is based on the commander's guidance and intent for fighting dirty, the scheme of maneuver, and the terrain. Included in the chemical officer's plan are the procedures for doing this and they are understood throughout the Brigade. Again, rehearsals are key for this to be successful.

A technique is the use of two military police (MPs) teams to escort the chemical reconnaissance team. The MPs provide additional security for the chemical reconnaissance team. Furthermore, they provide traffic control points (TCPS) as part of the marking procedures to guide units around the contaminated area. The key to this success was that the Fox crew immediately found the edges of the contamination and adequately marked the area. Pickets with VS-17 panels were used in this desert environment for marking. The current method of marking contaminated areas is not satisfactory for a desert environment. Furthermore, this technique was rehearsed and understood at the brigade through company team level.

The Brigade could have avoided the contaminated area and the logistical intensive decontamination operation that followed. Decontamination (decon) is the third element of chemical operations. Decon is conducted when a unit's avoidance measures fail and the unit becomes contaminated or the commander plans to fight contaminated if units become contaminated. There are three levels of decontamination operations: immediate, operational, and thorough. ${ }^{54}$ In this scenario, 
the Brigade performed immediate and thorough decontamination operations.

The first, immediate decon had minor success. The individual soldiers who preformed the immediate deconning were able to return to their units. While, the others became chemically contaminated casualties. The thorough decontamination operation requirements overwhelmed the Brigade.

As with the avoidance and protection principles, decontamination operations are planned as part of the MDMP process. The Brigade commander issues guidance as part of his initial guidance before the mission analysis concerning the requirements for decontamination operations. The Brigade chemical officer and chemical company commander develop the plan for covering the Brigade's area of operation. This implies that decontamination sites are planned throughout depth and width of the Brigade's sector, whether for defensive or offensive missions.

The sites are selected based upon type of mission, templated strikes, terrain, type of decon operation, road network, availability of water and decon assets. Typically, a Brigade has a decon platoon in direct support for a particular mission. The decon platoon is capable of performing operational and thorough decontamination operations. Once the sites are chosen, link-up points are establish to support the sites. Iink-up points are easily recognizable areas where the contaminated unit can report to the decon platoon leader and receive instructions about the decon operations. This is critical to prevent the spread of 
contamination and ensures the contaminated unit occupies the decon site correctly.

Limiting the spread of a persistent agent is a difficult task. If not done correctly, it requires a decontamination operation all its own. Terrain decon is also time consuming, resource intensive and can cause additional vehicles and personnel to become contaminated. Brigade chemical officers, along with the Logistics officer (S4), designate a road network specifically for contaminated vehicles. This is included in the decon plan, placed in the order and rehearsed at all levels.

The decon platoon requires additional equipment and personnel to assist in the decontamination operation. Engineer support provides assets for digging sumps and drainage trenches to control contaminated runoff to prevent further spread of contamination. Medical personnel render medical treatment to injured contaminated soldiers. Injured contaminated soldiers require decontamination before medical treatment is rendered. This procedure is rarely evaluated at the NTC. Why, because units are not prepared or trained in the proper procedures and lack the necessary treatment kits. Along with engineer and medical support, additional logistics are required.

A decon operation needs an extensive water resource for resupply. Logistics units will have to supply that capability if a water source is not located near the decon location. For example, in the scenario above, there were 78 vehicles requiring decontamination. Assuming all the vehicles were trucks, the decon 
platoon would need 35,100 gallons of water to do a detailed equipment decontamination. ${ }^{55}$

In this scenario, the Brigade was not prepared to conduct this type of an operation. Although decon operations were planned. It did not have the level of planning and coordination required to perform such an intensive decon operation as this. Contaminated units, coming from all directions, showed up at the actual decon site not the link-up point. Spreading contamination throughout the battle area.

The decon platoon has roughly a 5,000 gallon water hauling capability, assuming a water tanker is attached to the platoon for decon missions. With this amount of water, the platoon can decon roughly 12 vehicles before water resupply is necessary. Additionally, the operation ran longer than anticipated and the decon platoon was not prepared to conduct decon operations in the dark. The Brigade had to halt operations because of their lack of preparation for such a resource intensive operation.

These two scenarios are training exercises only. If they were actual events faced by Army Brigades, the effects would have devastated the units. The operations would have cost the lives of soldiers and the loss of equipment. The entire operations would be in jeopardy for the higher headquarters.

Chemical defense operations demand the same level of planning, preparation, and execution as any other operation. Chemical attacks could annihilate entire units or have a devastating psychological effect that renders soldiers ineffective. 
The need to simultaneously guard against vulnerability of a chemical attack and to conduct a conventional operation will impose contradictory pressures on a brigade commander's ability to plan future operations. Such dual concerns might prevent quick, decisive engagements in the future. Instead, Brigades may be forced to fight more at the low-intensity warfare level or to engage in a conventional battle of attrition while avoiding presenting the enemy with the opportunity for a knockout blow delivered by their chemical weapons.

Brigades training at the NTC are continually challenged to overcome this problem, a chemical attack in conjunction with an operation. More times than not, Brigades fail to anticipate the chemical attack and its impact on their operation. The results are devastating to the units.

The Brigades execute highly and largely avoidable tactical risk by failing to mount intelligence operations commensurate with the scope and tempo of their maneuver forces. Violating the first principle of chemical defense operations, avoidance. The Brigade S2 and Chemical officer fail to develop a thorough collection plan that includes all the assets available to the unit to confirm or deny the presence of chemical agent. The lack of understanding the capabilities of the assets available contribute to this problem.

Furthermore, Brigades fail to understand the scope of their operations with regards to protection and decontamination. Leaders believed that if everyone has a protective suit and mask, all is ok. Often soldiers became chemical casualties because they did not know how to properly wear the suit or were missing items. 
Decontamination operations are not appropriately planned or resourced.

The lack of emphasis placed on chemical defense training was consummated by the Brigade's poor performance under chemical warfare conditions. Chemical defense operations were not incorporated into the plan. Chemical defense planning, preparation, and execution require extensive forethought and application into the overall Brigade mission by the entire staff. More often than not, Brigades training at the NTC fail to accomplish this high level of visualization and planning.

\section{Conclusion.}

The NTC is the "measuring stick" for determining if Brigades are ready to go to war and operate under the most austere conditions. The Brigades conduct several different types of scenarios, under various constraints, one of which is chemical warfare. Overcoming chemical warfare is a challenge under any condition. Brigades faced with this challenge fail. When used by the enemy, chemical weapons impact on the synchronization of the entire mission, disrupting tempo, command and control, and causes a high casualty rate. The result is mission failure.

Why is it that Brigades fail to overcome the enemy's use of chemical weapons at the NTC? Chemical doctrine and techniques are adequate to support overcoming chemical weapon use, if applied. Doctrine dictates effective procedures to use when applying chemical defense principles. When chemical defense principles are 
applied to other doctrinal principles, they improve the Brigade's chances for success.

Chemical weapons have had a negative impact on Army operations since their first use in WWI. Today soldiers suffer from the same lack of training as those in WWI. However, unlike the soldiers of World War I, excellent equipment and doctrine exists to facilitate necessary training to survive and win in a contaminated environment.

Brigades enter into a mission totally unprepared for what may lie ahead. Intelligence-gathering assets are not poised to include enemy indicators about chemical weapons. Decontamination operations are afterthought operations and therefore are unsuccessful. This leaves the question, "Could Brigades conduct chemical defense operations if their lives depended on it?" The answer is no.

Some military theorists suggest that "military institutions fail because they fail to learn from past experience. Military institutions fail because they fail to anticipate the future. And, military institutions fail because they fail to adapt to the future." Im Implying U.S. Army units fail to adapt lessons learned from previous experiences. WWI units failed to adapt to the increasing use of chemical weapons. Even in Desert Storm, soldiers' lack of training and understanding of the chemical defense principles handicapped the Army units. Throughout its' use in the $20^{\text {th }}$ century, chemical weapons have posed an increasing threat to the unprepared. 
Whether the threat of chemical weapons use is perceived or real, Brigades must train and be ready to perform their missions in a chemically contaminated battlefield. Not a risk the U.S. Army can afford to take. Combat maneuver centers, like the NTC, are ideal settings for Brigades to hone their skills in chemical defense. Leaders at all levels must place the same emphasis on chemical defense training as they do for all other training requirements. This step is the first step in a solid chemical deterrence effort.

Adversaries are less likely to employ chemical weapons if their opponents are as equally prepared to defend against their use. The prevalence of a good chemical defense favors compliance with a chemical disarmament treaty by making chemical weapons less military useful. ${ }^{57}$ The more effective the defense an adversary faces, the more large-scale and therefore more easily detectable are the preparations the would-be violator is forced to make in order to achieve a militarily significant advantage. Should violations nevertheless occur, a strong chemical defense renders chemical use much less dangerous. ${ }^{58}$

Therefore, the current status, the Brigade's inability to operate on a contaminated battlefield requires re-evaluation of its current state of affairs. Currently around the world a formidable foe is preparing for a future conflict and is considering the use of chemical weapons to level the playing field. 


\section{End Notes.}

${ }^{1}$ Robb, Russell, and Paul V. Graham, Early History of Chemical, Smoke, Flame, and Biological Weapons,_American On Line, Nov, 1996

2 There is an ongoing debate in the military and congress concerning the employment of chemical weapons during the Persian Gulf War. Currently the final answer cannot be reached. Through current research material, the author will not claim one or the other.

3 Valerie, Adams, Chemical Warfare, Chemical Disarmament, (Bloomington and Indianapolis: Indiana University Press, 1990) 27.

4 United States. Department of Defense. Report of Chemical Warfare Review Commission., Washington: 1995, 10.

5 Brooks E. Keller and Dale Birdsell, The Chemical Warfare Service: Chemicals In Combat, (Washington, D.C.: Center of Military History, 1990) 5.

6 Ibid, 5

7 Charles E., Heller, MAJ(P), USAR, Chemical Warfare in World War I: The American Experience, 1917-1918, Leavenworth Papers, Combat Studies Institute, U.S Army Command and General Staff College, FT Leavenworth, Kansas, 1984. 9

${ }^{8}$ United States. Department of Defense. Report of Chemical Warfare Review Commission, Washington: 1995,11

9 Heller, 36,

${ }^{10}$ Keller and Birdsell, 16.

11 Donald W., Bailey, Poisonous Gas and the American Expeditionary Forces on World War One: Is It Still 1918? (SAMS Monograph, US Army Command and General Staff College, 1992), 13. The Germans, lacking sufficient manpower, gassed the $28^{\text {th }}$ and $77^{\text {th }}$ Divisions trying to cross the Vesle River. This technique halted the American divisions. Once they regrouped, the American divisions attacked across the river. Only to find that the Germans had retreated and left the ground saturated with chemicals that did not allow the divisions the opportunity to pursue.

12 Fredric J., Brown, Chemical Warfare A Study in Restraints, (Princeton, New Jersey: Princeton University Press, 1968) 33

13 A., Hadley, ITC, C., Beasley, MAJ, Bortner, T., Burns, J. Chalkley, I. "The Battle of Montfaucon" (Fort Leavenworth Kansas: Combat Studies Insititute, 1984), 19 


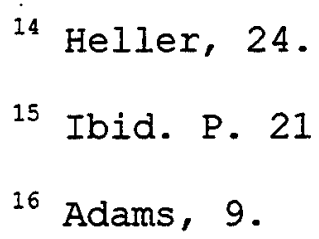

18 Robert Harris and Jeremy Paxman, A Higher Form of Killing: The Secret story of Chemical and Biological Warfare, (New York: Hall and Wong, 1982), 53

19 Ibid., 62

20 Geoffrey, BIainey The Causes of War, Third Edition (New York: The Eree Press, 1988) 279.

21 Almquist and Wiskell. The Problem of Chemical and Biological Warfare. Sipre, Vol. 1 (Stockholm: Humanties Press, 1971), 159.

22 US Army Field Manual 8-285, NAVMED P-5041, AFM 160-11. Treatment of Chemical Casualties and Conventional Military Chemical

Washington: Department of the Army, Navy, and Air Force, 28 February 1990. 8-1. The United States does not consider tear gas, also known as CS, as a chemical weapon. [T]hey are classified as riot control agents and used primarily in training and in riot control. Although under certain conditions and with presidential approval, riot control agents can be used in combat.

23 Rodney J., McEllroy Briefing Book on Chemical Weapons, Boston: Council for a Livable World Education Fund, October 1989.

24 Alleged Chemical Use, UN Chronicle. 20 (February 1983). 50.

25 Adams, 88

26 Edward M., Spiers, Chemical Weaponry, A Continuing Challenge, (New York: St. Martin's Press, 1989) 125.

27 Department of Defense, Conduct of the Persian Gulf War, Final Report to Congress, April 1992, P. Q-2.

28 Ibid. P. Q-3

29 Ibid. P. Q-10.

30 United States General Accounting Office, Report to Congressional Requestors, Chemical and Biological Defense, Emphasis Remains Insufficient to Resolve Continuing Problems, March 1996, 2. 
31 A conclusion reached by the author. After conducting research for this monograph much of the evidence suggest the same.

32 Aleksandr A., Svechin, STRATEGY, ed. Kent D. Lee (Minneapolis, Minnesota: East View Publications, 1992), 45

33 Richard A., Jackson, Colonel, Nuclear, Biological, and Chemical Defense in the $21^{\text {st }}$ Century, Center for Strategic Leadership, U.S. Army War College, Carlisle Barracks, PA., 4.

34 This report is required by Public Law 103-160, The FY94 National Defense Authorization Act and is included in the Department of Defense Nuclear/Biological/Chemical (NBC) Defense Annual Report to Congress, March 1997.

35 The National Security Strategy For A New Century, The White House. May 1997. 6.

36 William J., Perry, Honorable, Report of the Secretary of Defense to the President and the Congress, U.S. Government Printing Office, Wash. D.C., February 1995, 1.

37 Jackson, 3.

38 Robert G., Joseph, Regional Implications of NBC Proliferation, Joint Forces Quarterly, Autumn 1995,66.

39 Ronald, Smothers, U.S. Seizes 2 Georgia Men With Ties to Paramilitary Groups, (The New York Times, 27 April 1996), 9.

$40 \mathrm{~V}$ K. Nair, Brigadier, War in the Gulf, Lessons Learned for the Third World, (New Delhi: Iancer International, 1991), Throughout the book, Brig. Nair suggest that you use chemical and biological weapons to defeat the US military. The reason for their use is that the US military is not trained to react and therefore you can cripple their forces and exploit the success to your advantage.

41 This information was taken form the Fort Irwin home page available on the internet at

42 U.S. Army, Field Manual, 100-5, Operations, (Washington, D.C.: Department of the Army, 14 June 1993) 2-3.

43 U.S. Army, Field Manual, 3-100, Chemical Operations, Principles and Fundamentals, (Washington: Department of the Army, Marine Corps, 8 May 1996), 1-10. Avoidance is the application of passive and active defensive measures; camouflage and concealment, dispersion, recon, detection, warning, and limitation of contamination spread. Protection involves hardening of positions, application of MOPP, and individual and unit action before, during, and after an attack. Decontamination enhances 
survivability once an individual or unit is contaminated with chemical agent. Also, it is resource intensive.

44 U.S. Army, Field Manual 100-5, Operations, 6-3.

45 U.S. Army, Field Manual 101-5, Staff Organization and

Operations, (Washington D.C.: Department of the Army, 31 May 1997) 5-1.

46 Ibid, 5-3

47 U.S. Army, Field Manual 90-13-1, Combined Arms Breaching Operations, (Washington D.C.: Department of the Army, 28 February 1991) 2-1.

48 U.S. Army, Field Manual 34-130, Intelligence Preparation of the Battlefield, (Washington D.C.: Department of the Army, 8 July 1994) 1-1.

49 U.S. Army, Field Manual 100-5, Operations, 6-3

50 U.S. Army, Field Manual, 101-5, Staff Organization and Operations, 5-16.

51 U.S. Army, Field Manual, 3-7, NBC Field Handbook, (Washington D.C.: Department of the Army, 29 September 1994) 3-5. MOPP analysis determines the appropriate level of protective overgaments during operations. The analysis is an estimate of enemy's threat from chemical weapons and the type of operation the unit is performing. It is a management tool for commanders. They can adjust the amount worn based upon the threat.

52 U.S. Army, Field Manual, 101-5, Staff Organization and Operations, G-1.

53 Notes from the author's assignment as an Observer/Controller at the NTC.

54 U.S. Army, Field Manual, 3-5, NBC Decontamination, (Washington: Department of the Army, Marine Corps, 17 November 1993), 1-3. Immediate decontamination by individual soldiers is the process to minimize casualties by deconning the skin, personal wipedown, and operator's spraydown. Equipment is provided to the soldier for this process. Operational decon consist of vehicle washdown and MOPP gear exchange. This process allows a unit to fight longer and sustain its mission while contaminated. Thorough decon is a process to reduce the contamination of a unit to negligible risk. It is time consuming and requires extensive logistical support, such as water, manpower, and equipment.

55 Ibid, 10-6. The water figures were determined from the table in the manual. Using 200 and 250 as planning factors for vehicles. 
56 James, J., Schneider, Ph.D., What if We fight Tonight, Advanced Military Education for the XXIst Century. (Association of advanced Operational Studies NET CAII, Volume II, Number 2 FallWinter 1994-95) 3. Cohen Elliot and John Gooch, Military

Misfortunes, (New York: Free Press, 1990) passim. In his article, Dr Scheinder summarized one theme as outlined by Elliot and Gooch.

57 Matthew, Meselson, Ph.D., The Role of Chemical Defense in Chemical Warfare, Chemical Deterrence, and Chemical Disarmamentry, (Adapted from the Keynote address to the Sixth Annual Scientific Conference on Chemical Defense Research, U.S. Army Chemical Research, Development and Engineering Center, Edgewood Area, Aberdeen Proving Ground, Maryland, 13-16 November 1990), 1.

58 Ibid, 1, 2. 


\section{Bibliography.}

Adams, Valerie. Chemical Warfare, Chemical Disarmament. Indiana University Press, Bloomington and Indianapolis, 1990.

Almquist and Wiskell. The Problem of Chemical and Biological Warfare. Sipre, Vol. 1. Humanties Press, Stockholm, 1971).

Bailey, Donald W.. Poisonous Gas and the American Expeditionary Forces on World War One: Is It Still 1918? SAMS Monograph, US Army Command and General Staff College, 1992.

Bar, Michael. Strategic Lessons of Chemical War: Historical Approach. IDF Journal, Summer, 1990.

Bellamy, Chris. The Future of Land Warfare. ST. Martin's Press Inc. New York, New York, 1987.

Blainey, Geoffrey. The Causes of War, Third Edition. The FREE PRESS, A Division of Macmillan, Inc, New York, 1988.

Brown, Fredric J. Chemical Warfare: A Study in Restraints. Princeton, NJ: Princeton University, 1968.

Burck, Gordon M. and Charles C. Flowers. International Handbook on Chemical Weapons Proliferation. Westport, CT: Greenwood Press, 1991.

Cookson, John, and Nottingham, Judith. A Survey of Chemical and Biological Warfare. NY: Monthly Rev, 1969.

Department of Defense. Nuclear/Biological/Chemical (NBC) Defense Annual Report to Congress. March 1997.

Department of Defense. Conduct of the Persian Gulf War, Final Report to Congress. April 1992.

Fair, Stanley D. What's Wrong with Gas Warfare? Student Paper, Army War College, 8 Apr 1966.

Foley, William. Restraints in Gas Warfare. Military Review 43, October 1963.

Fort Irwin Home Page. American OnLine: http:// www. militarycity .com/ons/si.

Hadley, A., LTC, Beasley, C., MAJ, Bortner, T., Burns, J. Chalkley, L.. The Battle of Montfaucon. Combat Studies Institute, Fort Leavenworth Kansas, 1984. 
Harris, Robert, and Paxman, Jeremy. A Higher Form of Killing: The Secret Story of Chemical and Biological Warfare. NY: Hill and Wang, 1982

Heller, Charles E. MAJ(P). Chemical Warfare in World War I: The American Experience, 1917-1918. Combat Studies Institute, Leavenworth, KS, September 1984.

Jackson Richard A., Colonel, Nuclear, Biological, and Chemical Defense in the $21^{\text {st }}$ Century, Center for Strategic Leadership, U.S. Army War College, Carlisle Barracks, Pennsylvania, 1996.

Joseph Robert G.. Regional Implications of NBC Proliferation. Joint Forces Quarterly, Autumn 1995.

Keller, Brooks E. and Dale Birdsell, The Chemical Warfare Service: Chemicals In Combat. Center of Military History, Washington, D.C. 1990.

Leonard, James E. Chemical Warfare - A Urgent Need for a Credible Deterrent. Student Paper, Army War College, Apr 1982.

MCEllroy Rodney J.. Briefing Book on Chemical Weapons. Council for a Livable World Education Fund, Boston. October 1989.

Meselson, Matthew, Ph.D., The Role of Chemical Defense in Chemical Warfare, Chemical Deterrence, and Chemical Disarmamentry. Adapted from the Keynote address to the Sixth Annual Scientific Conference on Chemical Defense Research, U.S. Army Chemical Research, Development and Engineering Center, Edgewood Area, Aberdeen Proving Ground, Maryland, 13-16 November 1990.

Nair V K. Brigadier, War in the Gulf, Lessons Learned for the Third World. Lancer International, New Delhi, 1991.

Perry William J., Honorable, Report of the Secretary of Defense to the President and the Congress, U.S. Government Printing Office, Wash. D.C., February 1995.

Orton, Robert D. and Neumann, Robert C. The Impact of Weapons of Mass Destruction on Battlefield Operations. Military Review, December 1993.

Russell, Robb, and Paul V. Graham, Early History of Chemical, Smoke, Flame, and Biological Weapons,_American on Line, November, 1996.

Schneider, James, J., Ph.D.. What if We fight Tonight, Advanced Military Education for the XXIst Century. Association of advanced Operational Studies. NET CALL, Volume II, Number 2. Fall-Winter $1994-95$. 
Smothers Ronald, U.S. Seizes 2 Georgia Men With Ties to Paramilitary Groups. The New York Times, 27 April 1996.

Spiers, Edward M., Chemical Weaponry, A Continuing Challenge. St. Martin's Press, New York 1989.

Svechin, Aleksandr A.. STRATEGY. Ed. Kent D. Lee. East View Publications, Minneapolis, Minnesota, 1992.

The White House. The National Security Strategy For A New Century. May 1997.

UN Chronicle. Alleged Chemical Use. 20 February 1983.

U.S. Army. FM 3-5, NBC Decontamination. Department of the Army. Washington, D.C., 27 June 1990.

U.S. Army, Field Manual, 3-7, NBC Field Handbook. Department of the Army, Washington D.C.. 29 September 1994.

U.S. Army. FM 3-100, Chemical Operation, Principles and

Fundamentals. Department of the Army. Washington, D.C., 23 May 1991.

US Army Field Manual 8-285, NAVMED P-5041, AFM 160-11. Treatment of Chemical Casualties and Conventional Military Chemical Injuries. Department of the Army, Navy, and Air Force. Washington, 28 February 1990.

U.S. Army, Field Manual 34-130, Intelligence Preparation of the Battlefield. Department of the Army, Washington D.C., 8 July 1994.

U.S. Army, Field Manual 90-13-1, Combined Arms Breaching Operations. Department of the Army Washington D.C., 28 February 1991.

U.S. Army. FM 100-5, Operations. Department of the Army, Washington, D.C., June 1993.

U.S. Army. FM 100-5, Operations, (Initial Draft). Department of the Army, Washington, D.C., 4 April 1997.

U.S. Army, Field Manual 101-5, Staff Organization and Operations. Department of the Army, Washington D.C., 31 May 1997.

United States. Department of Defense. Report of Chemical Warfare Review Commission, Washington, 1995.

U.S. General Accounting Office. Chemical and Biological Defense Emphasis Remains Insufficient to Resolve Continuing Problems. Report to Congressional Requestors. United States General 
Accounting Office, Report to Congressional Requestors, Washington, March 1996.

U.S. General Accounting Office. Soldiers Inadequately Equipped and Trained to Conduct Chemical Operations. Report to Congressional Requestors. Washington: 1991.

Vogel, Fredrick J.. The Chemical Weapons Convention: Strategic Implications For The United States. 8 January 1997. 